\title{
2 \\ River Bank Erosion Assessment using 3D Hydrodynamic and Sediment Transport Modeling
}

\section{Juraj M. Cunderlik}

River bank erosion is one of the most damaging forms of water erosion. It causes loss of agricultural lands, recreational and industrial sites, and damaged hydraulic structures and infrastructure. It is also a major source of sediments entering river channels. A number of factors affect the rate of river bank erosion, including topography, climate, channel geometry, soil properties, type of vegetation, and human-induced changes to the fluvial system and land use.

An effective tool in controlling river bank erosion is the planning and installation of erosion control practices. Both structural and vegetative practices and their combinations are applied to river bank stabilization. These practices are aimed at reducing flow velocity, increasing shear stress of the soil, and armoring the affected river bank sections.

This chapter describes the application of the three-dimensional (3D) model ECOMSED to the design of river bank protection at a site in Ohio. ECOMSED is a hydrodynamic and sediment transport model designed to simulate time-dependent distributions of water levels, temperature, salinity, tracers, and cohesive and non-cohesive sediments in marine and freshwater systems. The model was chosen because of its capabilities to simulate 3D river flow and sediment transport through complex channel sections containing flow diversions and constrictions.

Cunderlik, J. 2007. "River Bank Erosion Assessment using 3D Hydrodynamic and Sediment Transport Modeling." Journal of Water Management Modeling R227-02. doi: 10.14796/JWMM.R227-02.

(C) CHI 2007 www.chijournal.org ISSN: 2292-6062 (Formerly in Contemporary Modeling of Urban Water Systems. ISBN: 0-9736716-3-7) 
Five scenarios of different river hydraulic conditions at the study site were simulated by the model. For each scenario, the model provided highresolution outputs of hydraulic parameters and sediment transport characteristics required for the river bank protection design. The outputs were plotted in GIS, and the locations most prone to bank erosion were identified. These locations were then compared to the locations of eroded river banks observed during a site visit.

The results showed that the model correctly identified river sections already affected by bank erosion. In addition, the model predicted another location where bank erosion is expected to develop in the near future. The erosion rates in the affected sections were found to depend on river flow conditions. The model indicated that due to the complex hydraulic conditions in the study section, some locations are more susceptible to erosion during lower river flow conditions than during certain high river flow conditions. The results were used to select and design river bank protection most appropriate for the site.

\subsection{Introduction}

River bank erosion is a dynamic geomorphologic process induced by natural or anthropogenic controls. Natural erosion usually occurs on alluvial floodplain rivers that dissipate their energy by horizontal channel migration in the floodplain. It is a central component of meander formation, channel migration and movement of sediments throughout the drainage basin (Lawler et al., 1997). Anthropogenic erosion is usually linked to intensive grazing, logging, construction of dams and flood control levees, channelization, river gravel extraction, urban development, and agricultural practices (Madej et al., 1994).

River bank erosion causes loss of agricultural lands, recreational and industrial sites, and damage of hydraulic structures and infrastructure. According to US ACE, $229,000 \mathrm{~km}$ of channels in the USA require erosion protection at an annual cost of C\$1 billion (Shields et al., 1995). River erosion can also have adverse impacts on sediment transport, channel morphology and flood carrying capacity further downstream (Downs and Simon, 2001). Barnes (1968) estimated that $480,000 \mathrm{~km}$ of eroding banks in the USA produced 450 million tons of sediments annually.

Bank erosion processes are commonly divided into three categories (Thorne, 1982): 
1. bank weathering and weakening (subaerial) processes;

2. fluid entrainment mechanisms; and

3. mass failure (bank collapse) processes.

According to Lawler et al. (1999), bank weathering is the most effective process in the upper reaches of river basins; fluid entrainment is prevalent in the middle reaches; and mass failure processes are dominant in the downstream reaches. The three bank erosion mechanisms operate at different levels of magnitude and frequency (Couper and Maddock, 2001).

There are numerous factors affecting the rate of river bank erosion. The most important factors include topography, climate (precipitation type, intensity and variability, and ground temperature), channel geometry, soil properties (mean particle size, clay and organic matter content, bulk density, permeability, cohesion, friction, cation exchange capacity, and pore water pressure), river hydraulic properties (depth, flow rate and velocity, shear stress, lift forces and turbulence), type of vegetation, and human-induced changes to the fluvial system and land use.

River banks have been shown to act as key sediment sources in many different drainage basins, and can supply over $50 \%$ of catchment sediment output (Lawler et al., 1999). In some river basins the contribution of bank eroded material to river sediment systems is over $80 \%$ (Imeson, 1974). Bull (1997) investigated sediment yields from individual bank erosion events within the upper River Severn, UK. The author found that at the annual timescale, the silt-clay fraction of bank-derived sediment accounted for an equivalent of $17 \%$ of the suspended load, increasing to an average of $38 \%$ at the monthly timescale, and then to an average of $64 \%$ at the event timescale.

Lawler et al. (1999) analyzed changes in bank erosion rates and variability along $130 \mathrm{~km}$ of the $3,315 \mathrm{~km}^{2}$ Swale-Ouse river system in northern England. The author concluded that bank erosion rates tended to peak in mid-basin, have strong seasonal variations, and the length of the erosion season increases downstream. The middle reaches of the system are characterized by high lateral channel mobility. The hypothesis is that the middle (piedmont) reaches are fluvially active because this is where a combination of peak stream powers and erodible bank materials are found (Hooke, 1995).

Winterbottom and Gilvear (2000) found that banks with inter-layered cohesive and non-cohesive sediments undergo the most erosion. Banks consisting entirely of non-cohesive gravels also have high rates of erosion, while the erosion of banks consisting of cohesive, laminated silts is generally very low. Nanson and Hickin (1986) performed a statistical analysis of mean lateral-migration rates for 18 meandering river channels in 
Western Canada. The authors concluded that river size and grain size of sediment at the base of the outer bank explain almost $70 \%$ of the volumetric migration rate of sand- and gravel-bed streams. Vegetation on the outer bank was found to have little significant effect in controlling channel migration.

Flood events often introduce hydraulic conditions under which the threshold of bank resistance is exceeded. Carroll et al. (2004) showed that bank erosion is significantly greater at flows above bankfull discharge when compared to flows confined to the main channel. Graf (1984) developed a method for assessing erosion risk based on the spatial location of areas of the floodplain relative to the river channel and the sum of the flood return periods for each annual flood occurring within a given time interval. Winterbottom and Gilvear (2000) refined Graf's method by using a GIS approach, and applied the technique to mapping probabilities of river bank erosion in Scotland.

An effective tool in controlling river bank erosion is the planning and installation of erosion control practices. Both structural and vegetative practices and their combinations are applied to river bank stabilization. The practices are aimed at reducing flow velocity, increasing shear stress of the soil, and armoring the affected river bank sections. The design of erosion control practices should include an evaluation of the possible impacts of the practices on ecological equilibrium of the river. According to Piégay et al. (1997), some practices may produce a spiral of interventions that increase flooding risk in the downstream floodplain by reducing bank roughness and increasing flow velocity in the managed reach. Shields et al. (1995) tested the effectiveness of different combinations of vegetation and structure practices in bank erosion control along seven channels in northwest Mississippi. They concluded that designs involving riprap toe protection and woody vegetation appeared to be most cost-effective.

There is a whole array of numerical river sediment transport and erosion models developed over the past two decades. SED2D is a sediment transport model developed by the U.S. Army Corps of Engineers Waterways Experiment Station under the Army Corps of Engineers Rehabilitation, Evaluation, and Maintenance Research Program. SED2D is a twodimensional (2D) model for depth-averaged transport of cohesive or a representative grain size of noncohesive sediments and their deposition, erosion, and formation of bed deposits (Donnell, 2006). MIKE 21 is a professional engineering software package with a $2 \mathrm{D}$ module for sediment transport simulation in rivers, lakes, estuaries, bays, coastal areas, and seas (DHI, 2005). GEMSS (Generalized Environmental Modeling System for Surface Waters) is an integrated system of three-dimensional (3D) 
hydrodynamic and transport models embedded in a geographic information and environmental data system (ERM, 2006). An in-depth evaluation of currently available numerical models for assessing fate and transport of contaminated sediments can be found in Imhoff et al. (2003).

This chapter describes the application of the 3D model ECOMSED to the design of river bank protection at a site in western Ohio. The 3D model was chosen because of its capabilities to simulate river flow and sediment transport through complex channel sections containing flow diversions and constrictions. The main objectives of the study were to:

1. test the model's ability to identify bank locations most prone to erosion;

2. study the erosion potential at the identified locations under various scenarios of river hydraulic conditions; and

3. select and design river bank protection most appropriate for the site.

The next section of the chapter describes the ECOMSED model. This is then followed by the description of the study area. The last section summarizes the main results.

\subsection{The ECOMSED model}

The ECOMSED model was developed in the mid 1980s (Blumberg, 2002). The current version of the model (ver. 3.1) was developed by HydroQual, Inc. in 2002. The model was designed to simulate time-dependent distributions of water levels, currents, temperature, salinity, tracers, cohesive and non-cohesive sediments, and waves in marine and freshwater systems.

ECOMSED has its origins in the Princeton Ocean Model (POM) developed by Blumberg and Mellor $(1980,1987)$, in the SEDZL model developed by Ziegler and Lick (1986) and Ziegler et al. (1990) at the University of California-Santa Barbara (Imhoff et al., 2003), and in the ECOM model (Blumberg, 1996). The model has a long history of successful applications to oceanic, coastal and riverine waters. A complete list of references related to various applications of the model can be found in Blumberg (2002).

ECOMSED has a modular structure. The main modules are:

1. hydrodynamic module;

2. surface heat flux module;

3. particle tracking module; 
4. sediment transport module; and

5. wave module.

The modules are designed to work in conjunction with one another. The user can flexibly select and use only those modules, which are required for a particular modeling task (Blumberg, 2002). The hydrodynamic and sediment transport modules were used in this study.

ECOMSED's hydrodynamic module (ECOM) is a 3D time-dependent model developed by Blumberg and Mellor $(1980,1987)$. ECOM can be run either in internal or external mode. When the internal mode is chosen, the hydrodynamic module runs in parallel with the sediment and tracer transport modules. The external mode of ECOM allows the model to use previously generated hydrodynamic information (hot-start option).

All the major physical processes that govern the barotropic and baroclinic components of water motion and mixing in natural waters are considered in ECOM. Turbulent closure formulations are incorporated in the module to provide internal simulations of horizontal diffusion and vertical diffusion processes (Imhoff et al., 2003). The ECOM module solves the RANS (Reynolds averaged Navier-Stokes) equations with the hydrostatic assumption and Boussinesq approximation. Prognostic state variables of ECOM include water temperature, salinity, water surface elevations and the $3 \mathrm{D}$ velocity field. The boundary conditions are specified as surface, bottom and open lateral (inflow and outflow) boundaries.

ECOMSED's sediment transport (SED) module can be used to simulate resuspension, deposition and transport of cohesive sediments, which are composed of clays, silts, and organic material. The suspended transport of non-cohesive sediments is calculated using the van Rijn procedure (van Rijn, 1984). Deposition and resuspension of cohesive sediments is modeled according to the methods of Krone (1962) and Gailani et al. (1991). The effects of bed armoring due to particle-size heterogeneity can also be included in non-cohesive sediment transport simulations. The sediment transport module can predict temporal and spatial distributions of (Blumberg, 2002):

1. suspended sediment concentrations (cohesive and noncohesive);

2. sediment bed elevation changes;

3. fluxes at the sediment-water interface; and

4. changes in sediment bed composition.

The SED module internally simulates settling, deposition and resuspension of single classes of cohesive and noncohesive particles. Water column-and-bed exchange of particles is represented as functions of bed 
shear stress and bed shear strength for cohesive solids and the Shields parameter for non-cohesive solids. Consolidation of the sediment bed is represented by a surface bed layer and multiple deep bed layers that respond to accumulation or erosion of solids from the bed (Imhoff, 2003).

Both ECOM and SED modules use a $\sigma$-coordinate system for better representation of irregular bottom topography with an orthogonal curvilinear grid in the horizontal plane. The orthogonal curvilinear coordinate system greatly increases model efficiency in treating irregularly shaped rivers and in meeting requirements for high resolution at desired locations (Blumberg, 2002). The ECOMSED program consists of subroutines written in FORTRAN 77. The subroutines were exported into Compaq Visual FORTRAN Developer Studio and linked and compiled into a stand-alone executable file. For further details of the model the reader is referred to Blumberg (2002).

\subsection{Application}

\subsubsection{Study Area Description}

The Stillwater River is located in western Ohio, USA. The river is one of Ohio's 11 state scenic rivers. The river begins in western Darke County and flows through western Ohio in a southeasterly direction to its confluence with the Great Miami River in Dayton (see Figure 2.1). The watershed of the Stillwater River to the section affected by erosion represents an area of $602 \mathrm{mi}^{2}$. There is no gauging station directly in the study section. The closest upstream station, the Stillwater River at Pleasant Hill (USGS ID. 03265000), measures runoff from around $80 \%$ of the watershed. The long-term annual mean flow at this station is $457 \mathrm{cfs}$ or $12.9 \mathrm{~m}^{3} / \mathrm{s}$ (approximately $600 \mathrm{cfs}$ or $17 \mathrm{~m}^{3} / \mathrm{s}$ in the study section). The historic peak flow of $51,400 \mathrm{cfs}$ or 1,455 $\mathrm{m}^{3} / \mathrm{s}$ (estimate) occurred in the Stillwater River at Pleasant Hill on March 25, 1913. The 100-y peak flow in the study section was estimated to be 23,100 cfs or $654 \mathrm{~m}^{3} / \mathrm{s}$ based on the SCS hypothetical storm type II (24-h storm with depth of 5.5 in or $140 \mathrm{~mm}$ ).

The Stillwater River in the study section is between 150 to $250 \mathrm{ft}$ (46 to $76 \mathrm{~m}$ ) wide. The main channel in the first half of the section is divided by a $700 \mathrm{ft}(213 \mathrm{~m})$ long and $50-100 \mathrm{ft}(15-30 \mathrm{~m})$ wide river island (see Figure 2.2). The island represents a constriction to the hydraulic capacity of the river and diverts the flow into two channels. The right channel (looking 
downstream) between the island and the river bank narrows to $80 \mathrm{ft}(24 \mathrm{~m})$ and the left channel to about $60 \mathrm{ft}(18 \mathrm{~m})$. The island is flooded when the river water elevation exceeds $805 \mathrm{ft}(245 \mathrm{~m})$ a.s.l. The mean water level and the top of the bank water level elevations at the upstream end of the island are $799 \mathrm{ft}$ a.s.l and $810 \mathrm{ft}$ a.s.l. respectively. The length of the channel in the study section is $2,300 \mathrm{ft}(701 \mathrm{~m})$ and the average slope of the channel bed is $0.07 \%$.

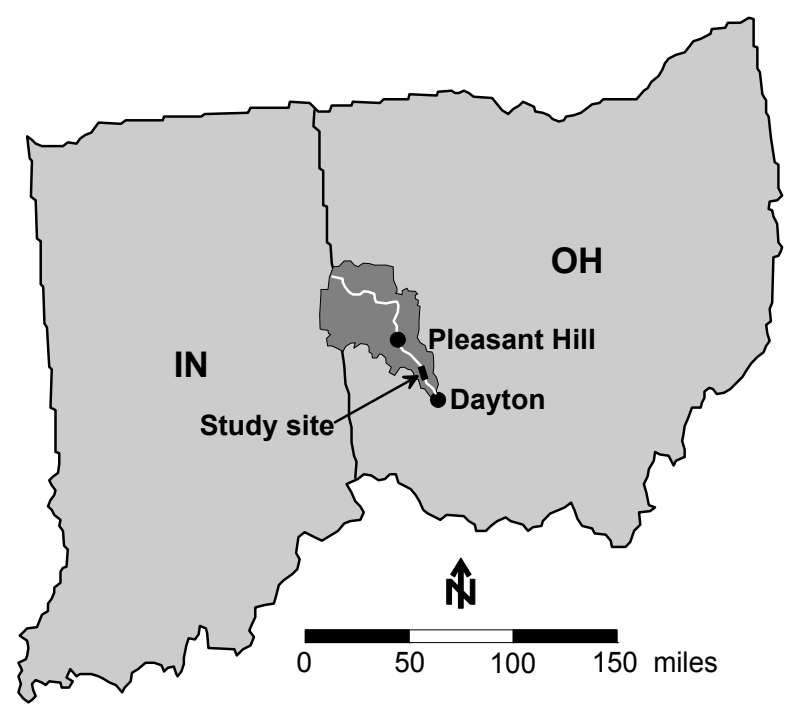

Figure 2.1 Location of the Stillwater River watershed.

Two locations affected by river bank erosion were observed during a site visit. The right river bank opposite the upper part of the island is the most affected location. The left river bank opposite the downstream end of the island shows indications of starting river bank erosion. At both locations the river bank recedes by channel incision, bank erosion, and slumping.

A detailed hydrologic and hydraulic analysis of the Stillwater River study section was performed to understand the flow regime of the River and its potential impact on river bank erosion. The objective of the analysis was also to derive a rating curve for the upstream boundary of the model as the flow rate corresponding to a given water elevation is a required input to the ECOMSED model. 


\subsubsection{Development of the 3D River Model}

The ECOMSED model uses a grid file to describe river channel morphology in a three-dimensional space. The 3D grid consists of irregularly shaped cells defined by width, length, and depth. The grid has the orthogonal curvilinear coordination system in the horizontal plane.

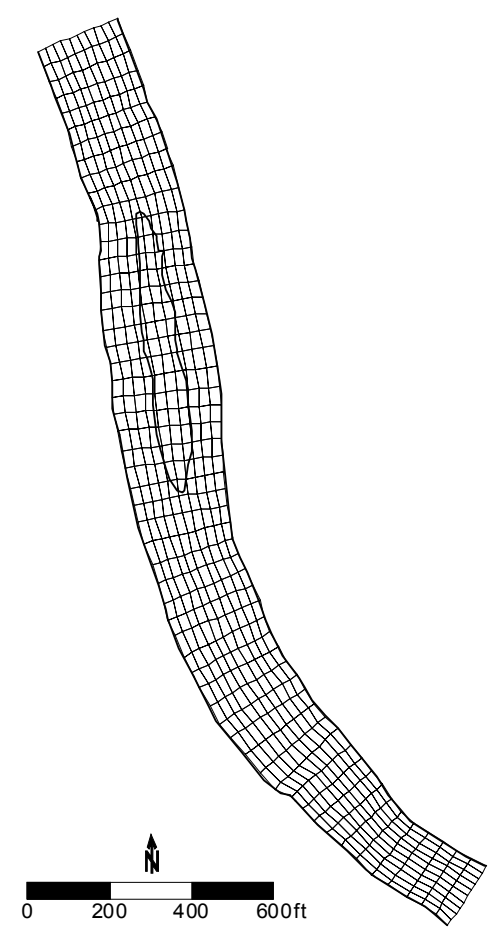

Figure 2.2 Model boundary and horizontal orthogonal curvilinear grid.

Ten cross-sections, dividing the study channel into nine 200-250 $\mathrm{ft}$ (61$76 \mathrm{~m}$ ) long sub-sections, were surveyed in the field. The cross-sectional data served as the basis for creating a 3D channel bed surface in GIS. The channel bed surface was then used to generate average depth of each cell column. Each column was vertically divided into four cells (layers) in accordance with the $\sigma$-coordinate system. 
The study section of the Stillwater River affected by bank erosion was divided into 2,736 cells ( 57 x 12 horizontal plane and 4 vertical layers). The first and last rows/columns of the horizontal plane define the model boundaries. A block of $20 \times 12 \times 4$ cells was added at the beginning and at the end of the model grid to minimize the effect of inflow/outflow boundary conditions on the study section. The grid has an average horizontal cell size of $20 \times 40 \mathrm{ft}(6 \times 12 \mathrm{~m})$. The average vertical height of the cell depends on simulated flow conditions. For mean flow conditions, the average water depth is about $2-5 \mathrm{ft}$. $(0.6-1.5 \mathrm{~m})$. For bankfull conditions the maximum water depth ranges from 7-15 ft. (2.1-4.6 m). The horizontal plane of the grid is depicted in Figure 2.2.

ECOMSED requires a known flow rate to be provided in the model upstream boundary condition. A stage-discharge curve was developed to estimate the flow rates corresponding to different river water level elevations. With the elevation at which a flow rate occurred being known it was then possible to modify the model grid file by adding or subtracting the depth from each cell.

\subsubsection{ECOMSED Modeling}

The numerical stability of the hydrodynamic module depends on the computational time step. ECOMSED prints out an acceptable range of time steps that can be used with a given model configuration. The time step used for the hydrodynamic modeling of the study section was set to 1 second. The length of the simulation period was set to 1 day.

The ECOM hydrodynamic model was run alone as well as in parallel with the sediment transport model. Every run started with a 24-h warm-up simulation that assured equilibrium conditions at the beginning of the actual simulation. A typical running time of the $2 \times 24-\mathrm{h}$ hydrodynamic simulation on a $3 \mathrm{GHz}$ Pentium computer was 4-5 h, and 10-12 h when combined with the sediment transport model.

The effect of surface waves on bottom friction was neglected in the model as this process is not important at this type and scale of modeling. Bottom shear stress was calculated using the diagnostic option with constant temperature and salinity. Key parameters of the hydrodynamic module are summarized in Table 2.1. For a detailed description of the parameters summarized in Table 2.1 see Blumberg (2002).

The SED module was run only for non-cohesive sediments because of the prevailing sandy river bed material in the study section. MPDATA (Multidimensional Positive Definite Advection Transport Algorithm) 
technique was used to simulate the transport of non-cohesive sediments. Initial sediment concentrations and sediment concentrations at open boundaries were set to zero to account only for sediments in the modeled river section. Due to the lack of detailed sedimentologic field data, usable for calibration and verification, the SED model parameters were estimated and the model was not calibrated. Therefore, only spatial trends rather than actual magnitude data were evaluated at this stage. This was also the reason why non-zero initial sediment concentrations were not considered in the modeling. The model was run to simulate sediment bed elevation change that would occur during a 24-h long period. Table 2.2 summarizes the key non-cohesive parameters used for the modeling of the Stillwater River.

Table 2.1 Hydrodynamic module parameters.

\begin{tabular}{lll}
\hline Parameter & Description & Value \\
\hline KB & Number of $\sigma$ levels [\#] & 4 \\
IKSL & Number of standard levels [\#] & 4 \\
BFRIC & Bottom friction coefficient [-] & 0.0025 \\
ZOB & Bottom roughness coefficient [m] & 0.0014 \\
HORCON & Coefficient of the Smagorinsky diffusivity [-] & $1.00 \mathrm{E}-01$ \\
UMOL & Background vertical diffusivity $\left[\mathrm{m}^{2} / \mathrm{sec}\right]$ & $1.00 \mathrm{E}-06$ \\
HPRNU & Horizontal Prandtl number [-] & 1 \\
VPRNU & Vertical Prandtl number [-] & 1 \\
TSI & Temperature $\left[{ }^{\circ} \mathrm{C}\right]$ & 20 \\
SSI & Salinity [psu] & 0 \\
QDIS & Discharge flow [cfs] & $600-16,530$ \\
\hline
\end{tabular}

Five different flow scenarios were simulated by the model. [Ed. Note: SI unit conversions have been omitted here for ease of reading]. These were the mean flow scenario (600 cfs corresponding to water surface elevation $799 \mathrm{ft}$ a.s.l.), a scenario representing flow conditions just before the island becomes flooded (4,000 cfs at $803 \mathrm{ft}$ a.s.l), a scenario representing flow conditions under which the island is completely flooded $(8,200 \mathrm{cfs}$ at $806 \mathrm{ft}$ a.s.l), left bank full flow scenario (12,080 cfs at $808 \mathrm{ft}$. a.s.l), and right bank full flow scenario $(16,530 \mathrm{cfs}$ at $810 \mathrm{ft}$ a.s.1). The following spatially distributed model outputs were evaluated:

1. flow velocity in the channel ( $\mathrm{ft} / \mathrm{s})$

2. bottom shear velocity ( $\mathrm{ft} / \mathrm{s})$, and

3. sediment bed elevation change ( $\mathrm{mm} / 24-\mathrm{h})$. 
Table 2.2 Sediment transport module parameters.

\begin{tabular}{lll}
\hline Parameter & Description & Value \\
\hline LAYMAX & Number of sediment bed layers $[\#]$ & 7 \\
FPBED & Fine sand fraction $[-]$ & 0.9 \\
D50VAR & Median grain size $[\mu]$ & 150 \\
WS2 & Settling speed of non-cohesive sediment $[\mu \mathrm{m} / \mathrm{s}]$ & 5,000 \\
DENNON & Bulk density of non-cohesive sediment bed $\left[\mathrm{g} / \mathrm{cm}^{3}\right]$ & 1 \\
SUSARM & Non-cohesive bed armoring constant $[-]$ & 0.5 \\
BEDTHI & Initial thickness of non-cohesive bed $[\mathrm{cm}]$ & 100 \\
CSI & Initial, spatially-constant non-cohesive sediment concentration $[\mathrm{mg} / 1]$ & 0 \\
CBDRYSL & Non-cohesive sediment concentration for each standard level $[\mathrm{mg} / 1]$ & 0 \\
CDIS & Non-cohesive sediment concentration of river discharge $[\mathrm{mg} / 1]$ & 0 \\
\hline
\end{tabular}

Shear velocity was used because the sediment motion criterion in Shields curve is related to shear velocity. If the shear velocity is known, then the size of bed material that will move can be determined. Shear velocity (shear stress) is also a parameter required in the design of bank stability measures.

\subsection{Results}

\subsubsection{Hydrodynamic Modeling}

Five different simulations were run by the model. The $600 \mathrm{cfs}$ (water surface elevation $799 \mathrm{ft}$ a.s.l) scenario led to a uniform distribution of flow velocities in most locations of the study section (results not shown). Figure 2.3 depicts vertically averaged river flow velocities for the 4,000 cfs (water surface elevation $803 \mathrm{ft}$ a.s.1.) simulation. The figure accurately demonstrates the effect of the flow constriction caused by the island, which is not flooded at this water surface elevation. The river flow velocities upstream of the island are uniformly distributed across the channel and range between 1 to $2 \mathrm{ft} / \mathrm{s}$. Maximum velocities are observed in the two channels diverted by the island. In particular, a maximum flow velocity of $8 \mathrm{ft} / \mathrm{s}$ was observed in the right channel along the bank affected by erosion. Downstream of the island, flow velocities again become uniformly distributed across the channel, which is dictated by the monotonous channel bed geometry. 


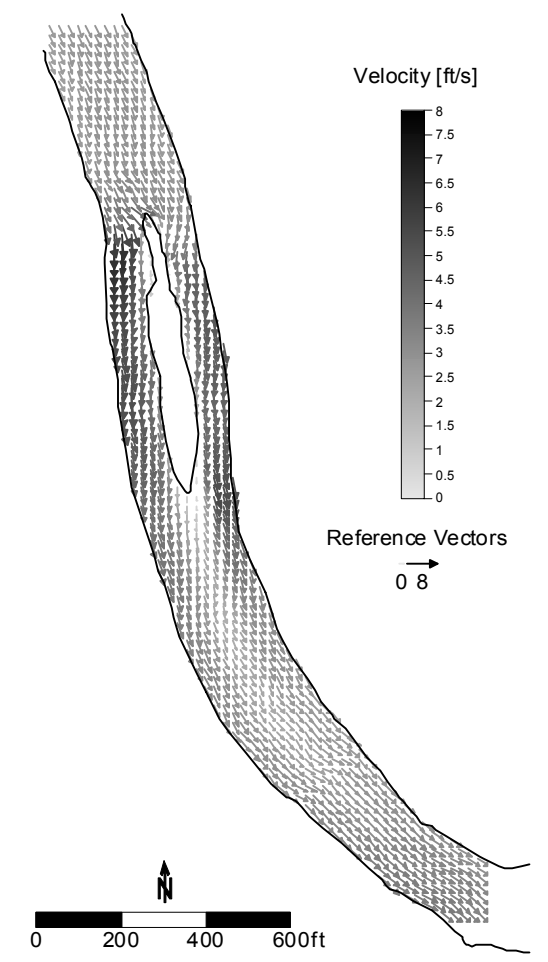

Figure 2.3 Vertically averaged flow velocities for the 4,000 cfs $\left(113 \mathrm{~m}^{3} / \mathrm{s}\right)$ flow scenario.

Figure 2.4 shows vertically averaged river flow velocities for the 8,200 cfs or $232 \mathrm{~m}^{3} / \mathrm{s}$ (water surface elevation $806 \mathrm{ft}$, or $245 \mathrm{~m}$, a.s.1.) simulation, when the island is completely flooded. The island still concentrates the flow along the river banks, however, as a result of increased cross-sectional area, flow velocities (up to $6 \mathrm{ft} / \mathrm{s}$ ) are now lower than those obtained from the previous scenario. The maximum flow velocities are now observed immediately upstream of the flooded island, in the location where flows are diverted by the submerged island. Another area with high flow velocities is located along the right bank at the downstream limit of the model. The location of the flooded island can be visually determined from the distribution of flow velocity vectors in Figure 2.4. The remaining scenarios $(12,080 \mathrm{cfs} / 808 \mathrm{ft}$ a.s.l and $16,530 \mathrm{cfs} / 810 \mathrm{ft}$ a.s.l) showed that the 
constriction effect of the island gradually vanishes as the depth of water in the channel increases (results not shown). For the 16,530 cfs bank-full scenario, flow velocities were high and uniformly distributed across the channel in the location of the flooded island.

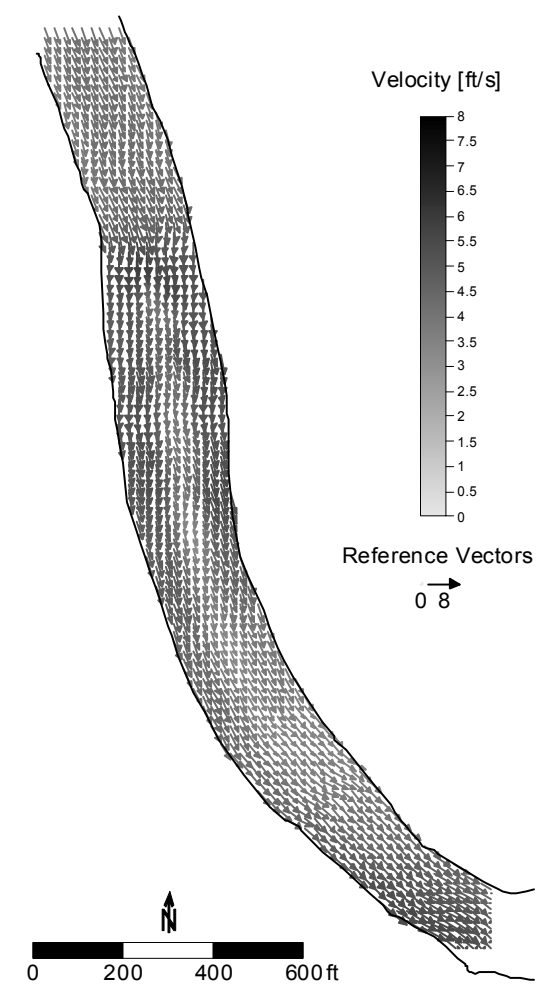

Figure 2.4 Vertically averaged flow velocities for the 8,200 cfs $\left(232 \mathrm{~m}^{3} / \mathrm{s}\right)$ flow scenario.

Shear velocities were also evaluated for the five different scenarios. The first scenario (600 cfs / $799 \mathrm{ft}$ a.s.l) identified two spots with shear velocities higher than $0.3 \mathrm{ft} / \mathrm{s}$. The first spot was located along the right bank opposite the upstream end of the island and the second along the left bank opposite the downstream end of the island (results not shown). Figure 2.5 depicts the distribution of shear velocities for the $4,000 \mathrm{cfs}$ (water surface elevation 803 $\mathrm{ft}$ a.s.l.) simulation, corresponding to flow conditions just before the island 
becomes flooded. The highest shear velocity (up to $0.5 \mathrm{ft} / \mathrm{s}$ ) occurs along the right river bank opposite the upstream end of the island. This coincides with field observations of erosion. Shear velocities along the downstream portion of the section are low (up to $0.2 \mathrm{ft} / \mathrm{s}$ ).

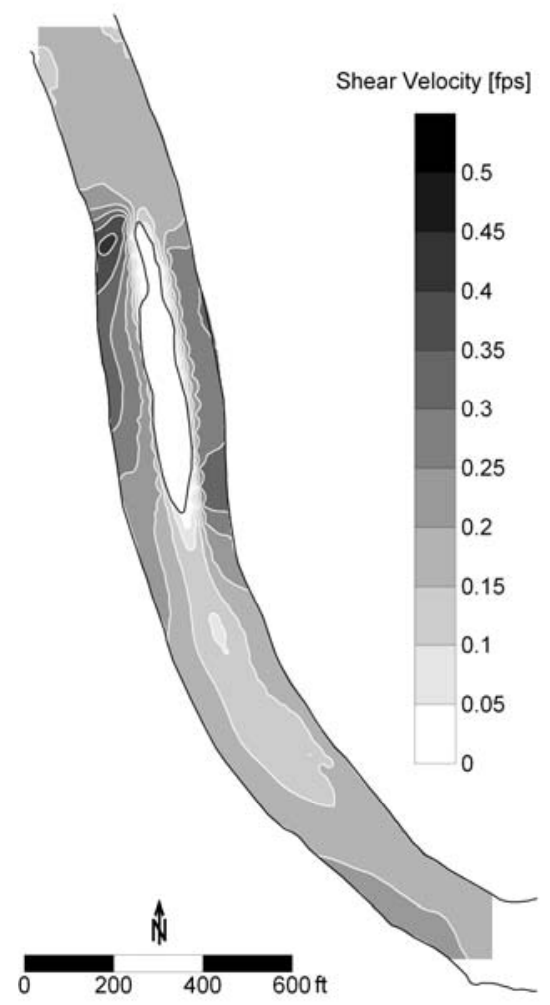

Figure 2.5 Distribution of shear velocities for the $4,000 \mathrm{cfs}\left(113 \mathrm{~m}^{3} / \mathrm{s}\right)$ flow scenario.

When the island is flooded, the spatial distribution of shear velocities is completely different. Figure 2.6 shows the shear velocity for the $8,200 \mathrm{cfs}$ (water surface elevation $806 \mathrm{ft}$ a.s.l.) simulation. The highest velocity is observed at the upstream end of the flooded island in the middle of the river. Shear velocities along the affected banks are rather uniform, ranging from 0.2 to $0.3 \mathrm{ft} / \mathrm{s}$. This pattern is also preserved in the results of the remaining two scenarios $(12,080 \mathrm{cfs} / 808 \mathrm{ft}$ a.s.l and $16,530 \mathrm{cfs} / 810 \mathrm{ft}$ a.s.l). The only 
exception is that shear velocities along the right river bank at the downstream limit of the model gradually increase up to $0.5 \mathrm{ft} / \mathrm{s}$ for the 16,530 cfs scenario.

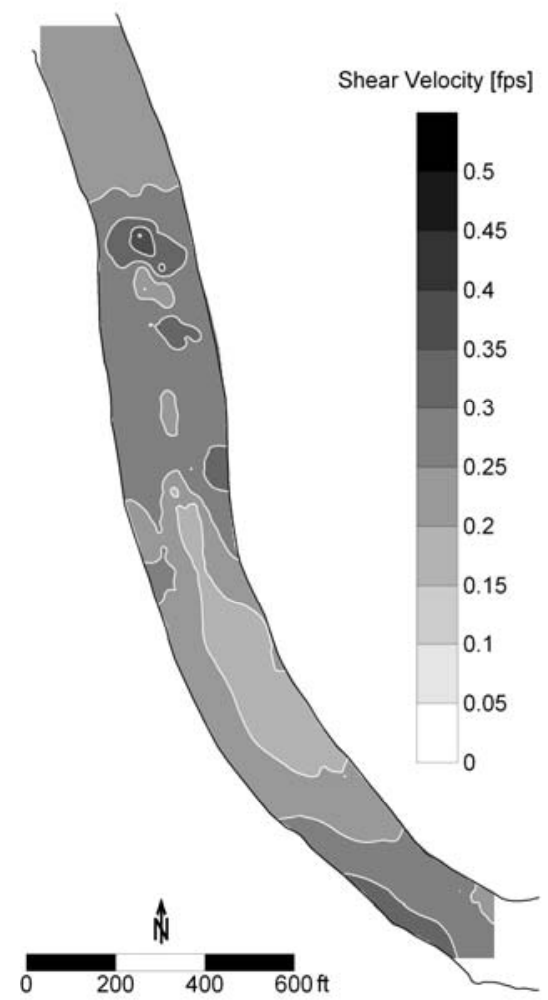

Figure 2.6 Distribution of shear velocities for the $8,200 \mathrm{cfs}\left(232 \mathrm{~m}^{3} / \mathrm{s}\right)$ flow scenario.

\subsubsection{Sediment Transport Modeling}

The sediment transport model was run to simulate sediment erosion and accumulation during a 24-h long period for the five different scenarios. Figure 2.7 summarizes the results in terms of sediment bed elevation change for the 4,000 cfs / $803 \mathrm{ft}$ a.s.1 scenario. The highest erosion of up to -1.5 in/24-h occurred along the right river bank opposite the upstream end of the 
island, which is the location most affected by erosion observed in the field. High erosion close to -1 in/24-h also occurred along the left bank opposite the downstream end of the island. Major sediment accumulation of approximately 1 in/24-h occurred downstream of the island in an approximately $750 \mathrm{ft}(229 \mathrm{~m})$ long strip located in the middle of the river.

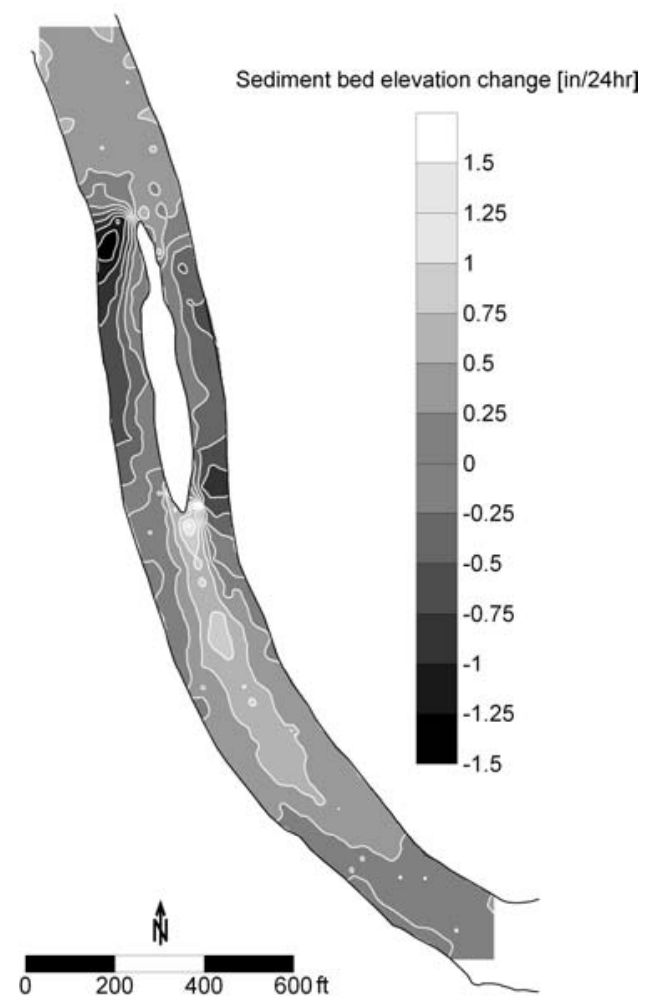

Figure 2.7 Sediment bed elevation change after 24 hours for the 4,000 cfs $\left(113-\mathrm{m}^{3} / \mathrm{s}\right)$ flow scenario.

The high-flow scenarios $((12,080 \mathrm{cfs} / 808 \mathrm{ft}$ a.s.l and $16,530 \mathrm{cfs} / 810 \mathrm{ft}$ a.s.l) led to a different erosion/accumulation pattern, where the highest erosion occurred in the upstream section of the flooded island (results not shown). Again, these results are preliminary only as the sediment transport model was not calibrated due to the lack of sedimentologic field data. 


\subsubsection{River Bank Protection Design}

The results from the hydrodynamic and sediment transport modeling were used to provide values of hydraulic parameters needed for the design of appropriate river bank protection and to identify sections susceptible to river bank erosion. Field observations confirmed that the right river bank opposite the island is the most affected location of the study section. The left river bank opposite the island shows indications of the beginning of erosion. No signs of erosion have yet been observed along the right river bank at the downstream limit of the model.

At present, the right river bank slope is unprotected and recedes by channel incision, bank erosion, and slumping. The bank height varies from 10 to $20 \mathrm{ft}$. (3-6 m). The bank is vegetated at most locations, with bare soil segments in the affected location. The preferred river bank protection design should provide a long-term solution to erosion prevention, and blend in with existing natural landscape. The second requirement is particularly important as the Stillwater River is one of Ohio's eleven designated scenic rivers.

There are a number of permanent protection options for sites affected by lateral bank erosion. Some of the options commonly used at sites with high flow velocities include rip-rap, concrete or asphalt aprons, and articulated concrete mats (ACMs). The ACMs are designed to vegetate over time and to look natural and preserve or restore habitat values. The vegetation provides additional bank stability, and an excellent fit into the environment since the ACMs will completely disappear as they become overgrown by vegetation.

\subsection{Conclusions}

River bank erosion causes enormous economic losses in forms of loss of urban and agricultural lands, damage to residential and industrial property and infrastructure, and excessive production of sediments entering the river system. For these reasons, river bank erosion is often perceived as a hazard by human society.

This chapter presented an application of the three-dimensional model ECOMSED to the design of river bank protection of the Stillwater River in western Ohio, USA. The model outputs identified three locations in the study section with high river bank erosion potential. These locations were compared to the locations with progressing erosion observed during a site visit. The model correctly identified the spatial extent of the two locations. 
The third location identified by the model is not yet observed in the field, but is susceptible to erosion during high river flow conditions according to the model results. River bank erosion is expected to develop at this location over time as part of natural river meandering.

The ECOMSED model proved to be a good predictive tool for the identification of river locations susceptible to erosion. The model can be very useful particularly for assessing impacts of man-made changes to the river system (e.g. construction of dams and flood control levees, channelization, and river gravel extraction) on river bank stability and sediment transport under various what-if scenarios.

The results obtained from the five scenarios of different river flow rates demonstrated the impact of complex hydraulic conditions on erosion potential in the study section. For example, the two locations along the left and right banks opposite the island have higher erosion rates when the island is an active constriction to the flow, diverting and concentrating the flow to the left and right channels. When the island becomes flooded, erosion rates drop due to an increase of the channel conveyance capacity. The erosion rates then rise up again under bank-full and overbank flow conditions. This is contrasted by the erosion potential at the downstream limit of the study section, which is high only during high river flow conditions.

The results from the hydrodynamic and sediment transport modeling were used to provide hydraulic parameters needed for the design of appropriate river bank protection. The Stillwater River is one of Ohio's eleven designated scenic rivers and therefore the preferred river bank protection design should provide a long-term solution to erosion prevention and blend in with existing natural landscape. The articulated concrete mats (ACMs) were selected as the preferred solution, given the high flow velocities in the river section. They are designed to vegetate over time and as such preserve the natural habitat.

Future work will be directed toward calibrating the sediment transport model. The model will also be used for evaluating the impacts of the installed ACMs on sediment transport and ecological equilibrium in the downstream sections of the river. 


\section{Acknowledgments}

The author would like to thank HydroQual, Inc., for providing the ECOMSED subroutines and documentation, James Moir, Colin Clarke and Jennifer Jantzen for helping with model input preparation, Dr. Alan Blumberg for his advising on ECOMSED modeling, and two anonymous reviewers for their comments and suggestions.

\section{References}

Barnes, R.C., 1968.Streambank erosion. Soil Conservation, 33/6, pp 126-128.

Blumberg, A.F. and G.L. Mellor, 1980. A Coastal Ocean Numerical Model. In:

Mathematical Modelling of Estuarine Physics, Proceedings of an International Symposium, Hamburg, August 24-26, 1978. J. Sundermann and K.P. Holz, Eds., Springer-Verlag, Berlin.

Blumberg, A.F. and G.L. Mellor, 1987. A Description of a Three-Dimensional Coastal Ocean Circulation Model. In: Three-Dimensional Coastal Ocean Models, N. Heaps, Ed., pp 1-16, American Geophys. Union.

Blumberg, A.F., 2002. A Primer for ECOMSED. HydroQual, Inc., USA.

Bull, L.J., 1997. Magnitude and variation in the contribution of bank erosion to the suspended sediment load of the River Severn, UK. Earth Surface Processes and Landforms, 22, pp 1109-1123.

Carroll, R.W.H., Warwick, J.J., James, A.I. and J.R. Miller, 2004. Modeling erosion and overbank deposition during extreme flood conditions on the Carson River, Nevada. Journal of Hydrology 297, pp 1-21.

Couper, P.R., and I.P. Maddock, 2001. Subaerial river bank erosion processes and their interaction with other bank erosion mechanisms on the River Arrow, Warwickshire, UK. Earth Surf. Process. Landforms 26, pp 631-646.

Couper, P.R., Space and time in river bank erosion research: a review. Area, 36.4, pp 387-403.

DHI, 2005. MIKE 21, Inland, Coastal Waters and Seas in 2D. Danish Hydraulic Institute, http://www.dhisoftware.com/mike21/.

Donnell, B.P. (Ed.), 2006. Users Guide to SED2D WES Version 4.5. US Army, Engineer Research and Development Center, Waterways Experiment Station, Coastal and Hydraulics Laboratory.

Downs PW, and A. Simon, 2001. Fluvial geomorphological analysis of the recruitment of large woody debris in the Yalobusha river network, Central Mississippi, USA. Geomorphology 37, pp 65-91.

ERM, 2006. GEMSS-HDM Hydrodynamic and Transport Module, Technical Documentation. Environmental Resources Management, Surfacewater Modeling Group.

Gailani, J., C. K. Ziegler, and W. Lick, 1991. The Transport of Sediments in the Fox River. J. Great Lakes Res., 17, pp 479-494. 
Graf, W.L. 1984. 'A probabilistic approach to the spatial assessment of river channel instability', Water Resour. Res., 20/7, pp 953-962.

Hooke, J. M. 1995. Processes of channel planform change on meandering channels in the U.K., in Gurnell, A. and Petts, G. (Eds), Changing River Channels. John Wiley \& Sons, Chichester, pp 87-115.

Imeson, A. C. 1974. The origin of sediment in a moorland catchment with particular reference to the role of vegetation. In Gregory, K. J. and Walling, D. E. (Eds), Fluvial Processes in Instrumented Catchments, Institute of British Geographers Special Publication, 6, pp 59-72.

Imhoff, J.C., Stoddard, A. and E.M. Buchak, 2003. Evaluation of contaminated sediment fate and transport models. Final Report. National Exposure Research Laboratory, Office of Research and Development, U.S. Environmental Protection Agency, Athens, Georgia 30605, $141 \mathrm{p}$.

Krone, R.B., 1962. Flume Studies of the Transport of Sediment in Estuarial Processes. Final Report, Hydraulic Engineering Laboratory and Sanitary Engineering Research Laboratory, University of California, Berkeley.

Lawler, D.M., Thorne, C.R. and J.M. Hooke, 1997. Bank erosion and instability. In Applied Fluvial Geomorphology for River Engineering and Management, Thorne CR, Hey RD, Newson MD (eds). Wiley, Chichester, pp 137-172.

Lawler, D.M., Grove, J.R., Couperthwaite, J.S. and G.J.L. Leeks. 1999. Downstream change in river bank erosion rates in the Swale-Ouse system, northern England. Hydrol. Process., 13, pp 977-992.

Madej, M.A., Weaver, W.E. and Hagans, D.K., 1994. Analysis of bank erosion on the Merced River, Yosemite Valley, Yosemite National Park, California, USA. Environmental Management, 18/2, pp 235-250.

Nanson, G.C. and E.J. Hickin, 1986. A statistical analysis of bank erosion and channel migration in western Canada. Geological Society of America Bulletin, v. 97, pp 497504.

Piégay, H., Cuaz, M., Javelle, E. and P. Mandier, 1997. Bank erosion management based on geomorphological, ecological and economic criteria on the Galaure River, France. Regulated Rivers: Research \& Management, 13, pp 433-448.

Shields, F.D., Bowie, A.J. and C.M. Cooper, 1995. Control of streambank erosion due to bed degradation with vegetation and structure. Water Resources Bulletin, 31/3, pp 475-489.

Thorne, C. R. 1982. Processes and mechanisms of river bank erosion, in Hey, R. D., Bathurst, J. C. and Thorne, C. R. (Eds), Gravel Bed Rivers. John Wiley \& Sons, Chichester, pp 227-259.

van Rijn, L.C., 1984. Sediment transport, part II: suspended load transport, ASCE J. Hydr. Engr., 110/11, pp 1613-1638.

Winterbottom, S.J. and D.J. Gilvear, 2000. A GIS-based approach to mapping probabilities of river bank erosion: regulated River Tummel, Scotland. Regul. Rivers: Res. Mgmt. 16, pp 127-140.

Ziegler, C.K. and W. Lick. 1986. A Numerical Model of the Resuspension Deposition and Transport of Fine Grained Sediments in Shallow Water. Report UCSB-ME-86-3. University of California Department of Mechanical Engineering, Santa Barbara, CA. 
Ziegler, C.K., J. Lick and W. Lick. 1990. SEDZL: A User-friendly Numerical Model for Determining the Transport and Fate of Fine-grained, Cohesive Sediments. UCSB Report, University of California at Santa Barbara, CA. 